\title{
INTRODUCTION TO URBAN AGRICULTURE
}

\author{
UVOD U GRADSKU POLJOPRIVREDU \\ L. Brezinščak, Ana Poštek, I. Kisić
}

\begin{abstract}
An increasing number of population in the cities has problems with food security, transportation and environmental protection. To mitigate these problems, a new type of agriculture has been established: Urban Agriculture (UA). In this paper, we are introducing the concept of UA and provide basic information on the definition and forms of UA. The article aims to provide insight into the general concept of UA for sustainable city development. UA has a positive influence on social, environmental and economic life in the cities, which should encourage members of the government and private sector to utilize UA as an important part in city planning. However, there are reservations which should be taken into account, but by raising awareness we add to a better understanding of mechanisms in UA.
\end{abstract}

Keywords: urban agriculture, sustainability, population growth

\section{SAŽETAK}

Sve veći broj stanovništva u gradovima dovodi do problema s opskrbom hrane, prijevozom roba i usluga i zaštitom okoliša. Kako bi se ublažile posljedice i ponudila rješenja, uspostavljena je nova vrsta poljoprivrede: Gradska poljoprivreda (GP). U ovom radu uvodimo koncept GP i dajemo osnovne informacije o definiciji i oblicima GP. Cilj je članka dati uvid u opći koncept GP kao podlogu za održivi razvoj grada. GP ima pozitivan utjecaj na društveni, okolišni i ekonomski život u gradovima, što bi trebalo potaknuti predstavnike grada i privatnog sektora da GP koriste kao važan dio u planiranju razvoja grada. Međutim, postoje ograničenja koja bi trebalo uzeti u obzir, ali povećanjem svijesti i objavom publikacija doprinosimo boljem razumijevanju GP.

Ključne riječi: gradska poljoprivreda, održivost, porast broja stanovnika 


\section{INTRODUCTION}

It is expected that by 2050 more than $60 \%$ of the world population will be living in urban areas (Ritchie, 2018). Achieving sustainable food production is proven to be challenging with current climate change (Reynolds, 2010). Agriculture contributes with around $30 \%$ of greenhouse gas emissions, but UA can lower mentioned values, especially of $\mathrm{CO}_{2}$ (Kulak et al., 2013). Extreme changes in rainfall patterns and temperatures are the leading reason for increased interest in UA. Also, lack of arable land in rural parts caused by land grabbing, undoubtedly sets off the movement of rural population towards urban areas. There are advantages and disadvantages to UA, which will be explained further in the paper. UA initiatives are happening worldwide, but for a different reason in developing and developed countries. While UA in developing countries is used primarily for food production, in developed countries it is linked with innovation, healthy lifestyle and community development (Tornaghi, 2014). Where ever in the world, UA could play a significant role in diminishing the negative effect of global warming while improving various aspects of life in the city. Alltogether, UA presents an opportunity for exploring and developing sustainable cities. This paper offers a brief introduction into UA initiative, by defining the importance of UA.

\section{Definition and importance of urban agriculture}

There have been many definitions and interpretations of the term urban agriculture, especially in the last two decades (Horst et al., 2017). Reason for such diversity is explained by Delgado (2018) who argues that the definition is context-dependent and related to the source of actors such as academia, local government, non-governmental organizations, hobbyist asnd many other enthusiasts. Nowadays, definitions by Smit et al. (2001), Mougeot (2000) are the most common, while in Croatia, Kisić (2018) offers the following definition: Urban agriculture is defined as agroeconomic activity located within or on the fringe of a city. It processes, distributes and sells food and products, grown with different intensity in smaller areas of the inner city (gardens, balconies, terraces, vacant lots, rooftops and public areas) or at the outskirts around the city, using local resources and recycling urban organic waste to grow different types of crop or livestock.

Agriculture inside city borders has been known since the year $2000 \mathrm{BC}$ in Egypt, China and India (Smit et al., 2001). In the beginning, with the sedentary lifestyle, it was a necessity, tied to basic food needs, but offering fresh, diverse 
foods and aesthetic enjoyment. Nevertheless, UA is not a relict of history because it was developing with the progress of cities (Vadnal and Alič, 2008).

Interestingly, at the end of the 19th century, Paris had $15 \%$ of the urban area under agriculture, producing over one million tonnes of vegetable yearly (Cockrall-King, 2012). Before and during World War II in the USA workingclass and immigrant households engaged in growing kitchen gardens and raising animals in urban settings as well as using open space for food production (Brinkley and Vitiello, 2014). In Croatia, in the middle of 19thcentury school gardens were established for multiple purposes, primarily esthetical and educational (Kolar-Dimitrijević, 2014). During world wars and in between them in the city of Zagreb, especially, Bulgarian immigrants started to cultivate soil within private gardens and paved the road for future city farmers (Glasnova, 2014). At the beginning of the $21^{\text {st }}$ century in Zagreb, there were several civil initiatives and even municipal activity, which led to the creation of several community gardens). In the last decade, University of Zagreb recognized the importance of UA, by starting an Interdisciplinary postgraduate specialist university study programme "Urban management" which has several modules associated with some aspect of UA (Kisić, 2018). To our knowledge, it is a unique course in South-East Europe.

According to Van Veenhuizen and Danso (2007), urban agriculture largely complements rural agricultural production. It increases the efficiency of the national food cycle, and it occupies rooftops, backyards and unused, rented or public areas. Typical products include fruits, vegetables, beans and berries, nuts, herbs and spices. Urban farmers are usually long-term urban residents, moderately poor and often women (Hovorka et al., 2009). UA can also make an extensive improvements to the socio-economic and environmental objectives of sustainable urban development (Mougeot, 2006; Pulighe and Lupia, 2016). It is almost impossible to calculate macroeconomic value, mostly because the production of food in UA is for self-consumption (Cabannes, 2006). However, UA contributes to the rise of employment, an increase of productivity of regional and local communities and to reducing food import (Peets, 2005).

Furthermore, De Zeeuw and Dubbeling (2009) note benefit such as proximity to urban consumers and lower transportation and cooling costs, which is particularly vital for quickly perishable products (e.g. leafy vegetables, dairy products, mushrooms, eggs). Environmental values come from the rejuvenation of abandoned and overgrown plots, recycling of organic wastes, increasing biodiversity, improving air quality (Wästfelt and Zhang, 2016). Unfortunately, 
there are several constraints and limitations for UA, and they are rarely analysed (Bokan and Lay, 2018). Firstly, a lack of available land or suitable space is the most significant limitation, most frequently caused by land grabbing (Borras and Franco, 2012). Secondly, due to air pollution, there are certain risks that leafy vegetables may contain high concentrations of heavy metals (Van Tuijl et al., 2018). Thirdly, the low interest of local government for endorsing or creating strategies for synergy development of city and UA. Fourthly, race and class-based disparity (Girardet, 2004; Cohen and Reynolds, 2014). Lastly, Thomaier et al. (2015) point out certain limits with production inside the city for acquiring specific certification (organic, local quality or traditional food).

In ever-changing urban dynamics, one can choose the form of urban agriculture that is best suited for his lifestyle and available space. However, UA has many different purposes, appears in many locations, and takes many forms (Kaufman and Bailkey, 2000; Dimitri et al,, 2015). There are three main categories: urban agriculture, urban farming and peri-urban (conventional or organic) agriculture (Kisić, 2018). Forms of urban agriculture adapted from Pulighe and Lupia (2016); Kisić (2018) are described in Table 1.

Table 1. Different forms of UA

\begin{tabular}{|l|l|}
\hline \multicolumn{1}{|c|}{ Form } & \multicolumn{1}{|c|}{ Description } \\
\hline Residental garden & $\begin{array}{l}\text { Private lot near the place of residing. Diversified } \\
\text { cultivation ranging from flowers to herbs and orchards. }\end{array}$ \\
\hline $\begin{array}{l}\text { Civic agriculture (balcony, terrace, } \\
\text { parking lots, rooftops) }\end{array}$ & $\begin{array}{l}\text { Use of boxes, pots or containers on private or public lots. } \\
\text { Usually for medicinal or aromatic herbs, but also } \\
\text { vegetables and fruits. For self-consumption and hobby. }\end{array}$ \\
\hline Public city park & $\begin{array}{l}\text { Managed by the local government. Dominated by } \\
\text { ornamentals and statutes. For enjoyment, exercise, } \\
\text { beautification of an area and social interactions. }\end{array}$ \\
\hline Institutional garden & $\begin{array}{l}\text { Parcel managed by organizations like the university, } \\
\text { religious centre, hospital and other non-profit organizations. } \\
\text { The production is generally for self-consumption and } \\
\text { education purposes. (Pulighe \& Lupia, 2016) }\end{array}$ \\
\hline Community gardens & $\begin{array}{l}\text { Municipality owned (rarely private) larger area, assigned } \\
\text { to local citizens. Inside, multiple plots managed } \\
\text { individually or by group (i.e. organization). Diverse types } \\
\text { of gardens, for self-consumption or horticultural therapy } \\
\text { and various other purposes. }\end{array}$ \\
\hline
\end{tabular}

Source: Adapted after Pulighe and Lupia (2016); Kisić (2018) 


\section{CONCLUSION}

Nowadays UA is not considered a relic of history anymore, contrarily in the last couple of decades around the world, different scientific and professional experiments were conducted. Certain interest from academia and public has arisen in Croatia only in the recent few years,. This paper provides basic information and a summary of what UA is capable of creating and providing to both agriculture and quality of life in urban regions. It gives the ability to individuals to make a change in their surroundings, influence others to connect with nature and promote a holistic approach. Hopefully, UA will not be just a fashion trend.

\section{REFERENCES}

1. Bokan, N., Lay, V. (2018.): Sociologijski aspekti urbanih vrtova: trendovi i dosezi proizvodnje hrane u gradovima. Socijalna ekologija: časopis za ekološku misao i sociologijska istraživanja okoline, 27(2): 141-164. https://doi.org/10.17234/SocEkol.27.2.2

2. Borras, S., Franco, J. (2012.): Global Land Grabbing and Trajectories of Agrarian Change: A Preliminary Analysis. Journal of Agrarian Change, 12(1): 34-59. https://doi.org/10.1111/j.1471-0366.2011.00339.x

3. Brinkley, C., Vitiello, D. (2014.): From farm to nuisance: Animal agriculture and the rise of planning regulation. Journal of Planning History, 13(2): 113-135. https://doi.org/10.1177/1538513213507542

4. Cabannes, Y., Raposo, I. (2013.): Peri-urban agriculture, social inclusion of migrant population and Right to the City. City, 17(2), 235-250. https://doi.org/10.1080/13604813.2013.765652

5. Cockrall-King, J. (2012.): Food and The City: Urban Agriculture and the New Food Revolution. New York: Prometheus Books.

6. Cohen, N., \& Reynolds, K. (2014.): Urban agriculture policy making in New York's "new political spaces": Strategizing for a participatory and representative system. Journal of Planning and Education Research 34(2): 221-234. https://doi.org/10.1177/0739456X14526453

7. Delgado, C. (2018.): Contrasting practices and perceptions of urban agriculture in Portugal. International Journal of Urban Sustainable Development, 10(2): 170-185. https://doi.org/10.1080/19463138.2018.1481069

8. De Zeeuw, H., Dubbeling, M. (2009.): Cities, food and agriculture: challenges and the way forward. Leusden: FAO-FCIT \& RUAF Foundation. Available at https://www.researchgate.net/profile/Marielle_Dubbeling/publication/2652695 88_CITIES_FOOD_AND_AGRICULTURE_CHALLENGES_AND_THE_W AY_FORWARD/links/55dc1aed08ae9d65949375a6/CITIES-FOOD-ANDAGRICULTURE-CHALLENGES-AND-THE-WAY-FORWARD.pdf 
9. Dimitri, C., Oberholtzer, L., Pressman, A. (2015.): The promises of farming in the city: introduction to the urban agriculture themed issue. Renewable Agriculture and Food Systems, 30(1): 1-2. https://doi.org/10.1017/S174217051400043X

10. Girardet, H. (2004.): Cities People Planet: liveable cities for asustainable world. Chichester: Wiley-Academy.

11. Glasnova, D. (2014.): Bugarski vrtlari u Hrvatskoj. Zagreb: Nacionalna zajednica Bugara u Republici Hrvatskoj.

12. Horst, M., McClintock, N., Hoey, L. (2017.): The intersection of planning, urban agriculture, and food justice: a review of the literature. Journal of the American Planning Association, 83(3): 277-295. https://doi.org/10.1080/01944363.2017.1322914

13. Hovorka, A., Zeeuw, H. d., Njenga, M. (2009.): Women feeding cities: Mainstreaming gender in urban agriculture and food security. Rugby: Action Publishing

14. Kaufman, J. L., Bailkey, M. (2000.): Farming inside cities: Entrepreneurial urban agriculture in the United States. Cambridge, MA: Lincoln Institute of Land Policy.

15. Kisić, I. (2018.): Gradska poljoprivreda. Zagreb: Univerity of Zagreb Faculty of Agriculture

16. Kolar-Dimitrijević, M. (2014.): Značenje školskih vrtova u sjevernoj Hrvatskoj u vrijeme Austro-Ugarske Monarhije. Ekonomska i ekohistorija - časopis za gospodarsku povijest $\mathrm{i}$ povijest okoliša, 10(1), 217-232. Available at https://www.ceeol.com/search/article-detail?id=429743

17. Kulak, M., Graves, A., Chatterton, J. (2013.): Reducing greenhouse gas emissions with urban agriculture: a life cycle assessment perspective. Landscape and urban planning, 111, 68-78.

18. Mougeot, L. J. (2000.): Urban agriculture: Definition, presence, potentials and risks, and policy challenges. Cities feeding people series; rept. 31. Available at https://idl-bnc-idrc.dspacedirect.org/bitstream/handle/10625/26429/117785. pdf? sequence $=12$

19. Mougeot, L. J. (2006.): Growing better cities: urban agriculture for sustainable development. Ottawa: International Development Research Centre.

20. Peets, J. (2005.): The Economics of Urban and Peri Urban Agriculture. In A. Viljoen (Ed.), Continuous Productive Urban Landscapes: Designing Urban agriculture for sustainable cities (pp. 65-73). Oxford: Architectural Press. 
21. Pulighe, G., Lupia, F. (2016.): Mapping spatial patterns of urban agriculture in Rome (Italy) using Google Earth and web-mapping services. Land Use Policy, 59(1): 49-58. http://dx.doi.org/10.1016/j.landusepol.2016.08.001

22. Reynolds M.P. (2010.): Climate change and crop production. Oxfordshire: CABI.

23. Ritchie, H. (2018.): Urbanization. Published online at OurWorldInData.org. Available at: https://ourworldindata.org/urbanization

24. Smit, J., Nasr, J., Ratta, A. (2001.): Urban agriculture yesterday and today. In: Urban Agriculture Food, Jobs and Sustainable Cities, 1-32. http://dx.doi.org/10.1016/S0022-3182(97)70254-1

25. Smit, J., Bailkey, M. (2006.): Urban agriculture and the building of communities. In R. van Veenhuizen (Ed.), Cities farming for the future: Urban agriculture for green and productive cities (pp. 145-170). Leusden: RUAF Foundation, IDRC and IIRR.

26. Thomaier, S., Specht, K., Henckel, D., Dierich, A., Siebert, R., Freisinger, U., Sawicka, M. (2015.): Farming in and on urban buildings: present practice and specific novelties of Zero-Acreage Farming (ZFarming). Renewable Agriculture and Food Systems, 30(1): 43-54. https://doi.org/10.1017/S1742170514000143

27. Tornaghi, C. (2014.): Critical geography of urban agriculture. Progress in Human Geography, 38 (4), pp. 521-567.

28. Vadnal, K. A., Alič, V. (2008.): Mestno kmetijstvo - oblike in izkušnje. Acta agriculturae Slovenica, 91, 191-212. Available at http://aas.bf.unilj.si/maj\%202008/16vadnal.pdf?

29. Van Tuijl, E., Hospers, G. J., Van Den Berg, L. (2018.): Opportunities and challenges of urban agriculture for sustainable city development. European Spatial Research and Policy, 25(2): 5-22. Available at https://www.ceeol.com/search/article-detail?id=758691

30. Van Veenhuizen, R., Danso, G. (2007.): Profitability and sustainability of urban and periurban agriculture (Vol. 19). Rome: FAO.

31. Wästfelt, A., Zhang, Q. (2016.): Reclaiming localisation for revitalising agriculture: A case study of peri-urban agricultural change in Gothenburg, Sweden. Journal of Rural Studies, 47: 172-185. http://dx.doi.org/10.1016/j.jrurstud.2016.07.013 
Author's address - Adresa autora:

Luka Brezinščak, mag. ing. agr.

e-mail: lbrezinscak@agr.hr

Prof.dr.sc. Ivica Kisić

University of Zagreb Faculty of Agriculture

Department of General Agronomy

Svetošimunska cesta 25

10000 Zagreb

Ana Poštek, mag. ing. agr.,

Kustošijanska 25

10000 Zagreb
Received - Primljeno:

18.02.2020. 